\title{
INDEKS HARGA SAHAM ASEAN-5 MEMEDIASI HUBUNGAN DARI THE FED TERHADAP KURS DI ASEAN-5 PADA PERIODE 2010-2019
}

\author{
Yoshua \\ Program Studi Magister Manajemen Universitas Tarumanagara \\ yoshua.tirtayasa@gmail.com \\ Yanuar \\ Program Studi Magister Manajemen Universitas Tarumanagara \\ Masuk : 06-06-2020, revisi : 30-06-2020 diterima untuk diterbitkan : 01-07-2020
}

\begin{abstract}
The purpose of this study was to determine the effect of The FED on Exchange Rates in ASEAN-5 during the period 2010-2019, using the ASEAN-5 stock price index as a mediating variable. At the same time want to confirm the theory of Mundell-Fleming. The type of this research is quantitative descriptive. By using the Eviews 10 program with the method of ordinary least square (simple linear regression). The results of this study are in Indonesia, Malaysia, Philippines and Singapura, ASEAN-5 composite stock price index variable can mediate the influence of the FED on the exchange rate except Vietnam.
\end{abstract}

Keywords: Mundell-Flemming, The FED, Composite Stock Price Index, Exchange Rate, ASEAN-5

Abstrak: Tujuan penelitian ini adalah untuk mengetahui pengaruh antara The FED terhadap Kurs di ASEAN-5 selama periode 2010-2019, dengan menggunakan indeks harga saham ASEAN-5 sebagai variabel mediasinya. Sekaligus ingin mengkonfirmasi teori MundellFleming. Adapun jenis penelitian ini adalah deskriptif kuantitif. Adapun hasil pada penelitian ini adalah pada negara Indonesia, Malaysia, Filipina dan Singapura variabel indeks harga saham gabungan ASEAN-5 dapat memediasi pengaruh The FED terhadap Kurs kecuali Vietnam.

Kata kunci: Mundell-Flemming, The FED, Indeks Harga Saham Gabungan, Kurs, ASEAN-5

\section{PENDAHULUAN}

\section{Latar Belakang}

Pada dunia perekonomian saat ini, interaksi sebuah negara dengan dengan masyarakat dunia lain (negara asing) sudah lumrah terjadi dalam bentuk perdagangan internasional. Namun aktivitas perdagangan internasional (makro ekonomi) tidak terlepas dari kebijakan moneter dan fiskal yang diambil oleh pemerintah untuk menangani permasalahan tersebut (Sukirno, 2011). Hal ini juga yang menentukan apakah suatu negara menganut perkeonomian terbuka atau tertutup terhadap aktivitas internasional.

Model Mundell-Flemming adalah model yang dibuat oleh Robert Mundell dan Marcus Flemming, dengan perfect capital mobility, dimana modal akan mengalir bebas lintas negara ke arah tingkat pengembalian (return) yang lebih tinggi (Yanuar, 2016). Suatu negara bisa meminjam atau memberi pinjaman sebanyak yang di inginkan pasar keuangan dunia. Jika tingkat bunga lebih tinggi itu akan memberi pinjaman ke negara lain. Teori dari MundellFlemming ini menarik untuk diteliti karena masih belum banyak penelitian yang dilakukan untuk mengetahui/mengkonfirmasi hal ini. yaitu perubahan suku bunga The FED terhadap kurs dinegara lain dengan menggunakan mediasi indeks harga saham. Hal ini diperkuat menurut Dai (2018) bahwa nilai tukar rentan terhadap dana investor asing, istilahnya hot money, investor pindah-pindah. Mencari investasi yang lebih menguntungkan. 
Negara Amerika serikat merupakan negara yang memiliki peran ataupun kendali cukup besar terhadap perekonomian diseluruh dunia. Adapun kebijakan yang biasa diambil oleh Amerika adalah menaikan atau menurunkan suku bunga acuan yaitu The fed. Tetapi perubahan suku bunga The FED tidak secara langsung mempengaruhi nilai di negara Asean, tetapi melalui saham.

Saham merupakan media untuk melakukan perpindahan dana tersebut, karena pasar modal adalah tempat atau sarana bertemunya antara permintaan dan penawaran instrumen keuangan jangka panjang, umumnya lebih dari 1(satu) tahun (Samsul, 2006). Karena adanya literatur gap, dengan pengunaan variabel mediasi yaitu indeks harga saham. Ada ketertarikan penulis untuk mengkonfirmasi teori Mundell - Flemming. Berdasarkan dari literatur terdahulu tentang pengaruh The fed terhadap indeks harga saham serta pengaruh indeks harga saham terhadap kurs sudah pernah diteliti sebelumnya. Sehingga penulis berharap dengan pengunaan variabel mediasi ini dapat memenuhi literatur gap tersebut.

Berdasarkan data dari databoks yang dikutip dari Lidwina (2019) terdapat 10 negara dengan tujuan investasi asing di Asia. Dari data tersebut dapat diketahui bahwa ASEAN merupakan tujuan utama investasi asing. Dari daftar negara tersebut terdapat 5 negara yang termasuk dalam daftar bagian dari ASEAN - 5 (Indonesia, Vietnam, Singapura, Filipina dan Malaysia). Sehingga dapat disimpulkan bahwa portfolio investasi asing di wilayah ASEAN cukup tinggi dan diminati oleh investor. Dari paparan yang telah dijelaskan diatas, maka penulis tertarik untuk melakukan penelitian dengan Judul "Indeks Harga Saham ASEAN-5 Memediasi hubungan dari The fed Terhadap Kurs di ASEAN-5 pada periode 2010 2019".

\section{Tujuan Penelitian}

1. Bagaimana pengaruh The fed terhadap indeks harga saham di ASEAN-5 pada tahun 2010 -2019 ?

2. Bagaimana pengaruh antara indeks harga saham ASEAN-5 dengan kurs di ASEAN-5 pada tahun 2010 - 2019 ?

3. Bagaimana pengaruh antara The fed terhadap kurs di ASEAN-5 dengan menggunakan indeks harga saham ASEAN-5 sebagai variabel mediasinya pada tahun 2010 - 2019 ?

\section{TINJAUAN PUSTAKA}

Mundell - Flemming berpendapat "The world is still a closed economy, but its regions and countries are becoming increasingly open. The trend, which has been manifested in both free movement of goods and increased mobility of capital, has been stimulated by dismantling of trade and exchange controls in Europe, the gradual erosion of the real burden of tariff protection, and the stability unparalleled since 1914, of the exchanges rates. The international economic climate has changed in the direction of financial integration and this has important for economy policy" (Ugur, 2002). Yang dapat disimpulkan bahwa saat ini dunia masih ekonomi tertutup, tetapi wilayah negara akan semakin terbuka. Dengan tren perpindahan barang dan modal akan semakin meningkat. Hal ini telah terlihat dari perdagangan dan pertukaran di Eropa dengan nilai tukarnya. Yang menyebabkan perubahan iklim keuangan (ketika ekonomi terbuka maka investor akan dapat dengan mudah memindahkan dananya ke negara lain yang memberikan return yang lebih besar dengan risiko yang sesuai toleransi mereka). Dengan adanya perdagangan internasional tentu akan memperoleh banyak manfaat bagi negara tersebut seperti. Meningkatkan persahabatan antar negara, kebutuhan setiap negara dapat tercukupi, mendorong kegiatan produksi barang secara maksimal mendorong kemajuan ilmu pengetahuan dan teknologi, setiap negara dapat mengadakan spesialisasi produksi dan memperluas lapangan pekerjaan (Setiawan dan Lestari, 2011).

Jika The fed naik maka akan membuat pergerakan saham cenderung turun, hal ini diperkuat oleh pendapat (Aini,2018) dengan masih adanya persepsi di pasar The fed akan agresif menaikan suku bunga acuannya menjadi salah satu faktor yang membuat pergerakan 
saham cenderung melemah. Hal ini juga sesuai dengan pendapat Mahrofi (2005) yang mengatakan bahwa kenaikan suku bunga The fed menjadi biang utama tertekannya bursa global termasuk IHSG. Adapun penyebab melemahnya menurut Richard (2018) investor akan membuat keputusan untuk keluar sementara dari negara berkembang, hingga benar-benar kepastian itu muncul. Sehingga banyak juga mata uang yang negara berkembang terdepresiasi.

Ketertarikan penulis untuk mengkonfirmasi pengaruh The Fed terhadap Kurs dengan Indeks Harga Saham sebagai variabel mediasinya, belum penulis temukan. Namun berdasarkan penelitian yang telah dilakukan oleh Yang \& Hamori (2013), Gom (2015) serta Wijayaningsih et all (2016) terdapat pengharuh siginifikan antara The fed terhadap indeks harga saham. Sedangkan Pada pengaruh indeks harga saham terhadap kurs penelitian yang dilakukan oleh Tsai (2012), Mitra (2017) serta Tang \& Yao (2018) menyimpulkan pengaruh yang signifikan.

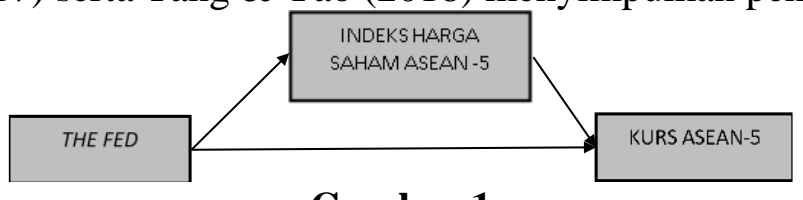

Gambar 1

Kerangka Pemikiran Penelitian

\section{METODE PENELITIAN}

Jenis pada penelitian yang dilakukan oleh penulis yaitu deskriptif, kuantitatif. Pengunaan variabel mediasi pada penelitian ini adalah menggunakan indeks harga saham pada negara di ASEAN-5. Sumber data yang digunakan dalam penelitian ini adalah data sekunder yaitu data yang diperoleh melalui pihak lain, tidak langsung diperoleh oleh peneliti dari subjek penelitiannya (data tangan kedua). Adapun pengolahan menggunakan program Eviews 10 dengan metode ordinary least square (regresi linier sederhana). Periode yang diteliti pada penelitian ini dari tahun 2010 - 2019 dengan fokus pada negara ASEAN - 5.

\section{Tabel 1}

Operasionalisasi Variabel

\begin{tabular}{|l|l|l|l|}
\hline Variabel & Simbol & Keterangan & Data \\
\hline Variabel Dependen & $Y_{I}$ & Kurs ASEAN-5 & USD / Terhadap mata uang asal \\
\hline Variabel Independen & $X_{I}$ & The fed & Persen \\
\hline Variabel Mediasi & $M$ & Indeks Harga Saham ASEAN-5 & Unit \\
\hline
\end{tabular}

\section{HASIL DAN KESIMPULAN}

\section{Hasil}

Pada penelitian ini menggunakan aplikasi Eviews 10 untuk mengolahnya. Adapun rangkaian nya adalah melakukan uji asumsi klasik yang terdiri dari uji normalitas, uji autokorelasi dan uji heteroskedastisitas. Untuk uji multikolinieritas tidak penulis lakukan karena multikolonieritas adalah kondisi adanya hubungan linier antar variabel independent, maka multikolonieritas tidak adak terjadi pada persamaan regresi sederhana (yang terdiri atas satu variabel dependen dan satu variabel independen) (Winarno, 2015). Adapun pada negara Vietnam penulis tidak melakukan Interpretasi lebih lanjut karena ada permasalah pada uji normalitas. Kemudian penulis melanjutkan dengan uji $\mathrm{T}$ (parsial) \& uji $\mathrm{R}^{2}$ (koefisien determinasi), dengan kesimpulan yaitu The fed berpengaruh terhadap kurs pada negara di ASEAN -5 dengan penggunaan indeks harga saham sebagai variabel mediasinya. Berikut adalah hasil dari uji $\mathrm{T} \& \mathrm{Uji} \mathrm{R}^{2}$, yang terdapat pada tabel dibawah ini :

\section{Tabel 2}

Output Uji T \& Uji Koefisien Determinasi (R2)

\begin{tabular}{|c|c|c|c|c|}
\hline Negara & Model X ke Y & $\begin{array}{c}\text { Hasil Uji T / } \\
\text { Adjusted } R \text {-Squared }\end{array}$ & Model X ke Y & $\begin{array}{c}\text { Hasil Uji T / } \\
\text { Adjusted R-Squared }\end{array}$ \\
\hline Indonesia & Thefed $\rightarrow$ IHSG & $\begin{array}{c}* * *(0.0000) \\
0.797296(79.73 \%)\end{array}$ & IHSG $\rightarrow$ Rupiah & $\begin{array}{c}* * *(0.0000) \\
0.684413(68.44 \%)\end{array}$ \\
\hline Malaysia & Thefed $\rightarrow$ KLSE & $\begin{array}{c}* * *(0.0222) \\
0.043514(4.35 \%)\end{array}$ & KLSE $\rightarrow$ Ringgit & $\begin{array}{c}* * *(0.0009) \\
0.089310(8.93 \%)\end{array}$ \\
\hline
\end{tabular}




\begin{tabular}{|c|c|c|c|c|}
\hline Filipina & Thefed $\rightarrow$ PSEI & $\begin{array}{c}* * *(0.0006) \\
0.224329(22.43 \%)\end{array}$ & PSEI $\rightarrow$ Peso & $\begin{array}{c}* * *(0.0000) \\
0.99783(99.78 \%)\end{array}$ \\
\hline Singapura & Thefed $\rightarrow$ SET & $\begin{array}{c}* * *(0.0007) \\
0.092780(9.28 \%)\end{array}$ & SET $\rightarrow$ SGD & $\begin{array}{c}* * *(0.0000) \\
0.498512(49.85 \%)\end{array}$ \\
\hline
\end{tabular}

Keterangan

$* * *$ signifikan $1 \%(0.01)$

$* *$ = singifikan $5 \%(0.05)$

$*=$ signifikan $10 \%(0.10)$

Sumber: diolah penulis dari hasil regresi eviews

Indonesia

The fed Berpengaruh terhadap Kurs Rupiah dengan Indeks Harga Saham Gabungan Indonesia sebagai variabel mediasinya

Berdasarkan hasil regresi pada The fed terhadap Indeks Harga Saham Gabungan Indonesia menghasilkan pengaruh positif (Probabilitas 0.0000, koefisien 13.59229), dan juga pada hasil regresi Indeks Harga Saham Gabungan Indonesia terhadap Rupiah menghasilkan pengaruh positif (probabilitas, 0.0000, koefisien 15.99709). Hal ini dapat disimpulkan bahwa dengan menggunakan variabel mediasi Indeks Harga Saham Gabungan Indonesia mengahasilkan pengaruh dari The fed terhadap Kurs Rupiah di Indonesia. Pada model regresi The fed terhadap Indeks Harga Saham Gabungan Indonesia, tidak sesuai dengan penelitian terdahulu yang telah dilakukan oleh Yang Lu \& Hamori Shigeyuki (2013) dimana The fed terhadap Indeks Harga Saham Gabungan Indonesia memiliki pengaruh negatif pada periode tahun 2008 - 2012. Kemudian pada penelitian yang dilakukan oleh Gom Hotneri Gom (2015) pada periode 2008 - 2013 Indeks Harga Saham Gabungan Indonesia juga memiliki pengaruh negatif terhadap Kurs Rupiah. Untuk model regresi yang kedua yaitu Indeks Harga Saham Terhadap Kurs Rupiah, sesuai dengan penelitian yang dilakukan Tsai I Chun (2012) yaitu terjadi pengaruh antara Indeks Harga Saham Gabungan di Indonesia terhadap Kurs Rupiah. Pada penelitian tersebut periodenya adalah dari tahun 1992 - 2009. Terjadi pebedaan pada hasil regresi antara The fed terhadap Indeks Harga Saham Gabungan Indonesia, yaitu terjadi pengaruh negatif pada penelitian terdahulu sedangkan pada penelitian penulis terjadi pengaruh positif. Perbedaan tersebut bisa saja terjadi karena adanya perbedaaan rentang waktu penelitian. Penulis pun menemukan bahwa pada tahun penelitian penulis di periode 2015 - 2019 The fed cenderung menaikan suku bunga nya, namun pada Indeks Harga Saham Indonesia dari periode penelitian penulis cenderung meningkat karena itu pengaruh nya menjadi positif.

Malaysia

The fed bepengaruh terhadap Kurs Ringgit dengan Indeks Harga Saham Gabungan Malaysia sebagai variabel mediasinya

Berdasarkan hasil regresi pada The fed terhadap Indeks Harga Saham Gabungan Malaysia menghasilkan pengaruh positif (Probabilitas 0.02222, koefisien 2.316960), dan juga pada hasil regresi Indeks Harga Saham Gabungan Malayasia terhadap Kurs Ringgit menghasilkan pengaruh positif (probabilitas, 0.0009, koefisien 3.401773). Hal ini dapat disimpulkan bahwa dengan menggunakan variabel mediasi Indeks Harga Saham Gabungan Malaysia mengahasilkan pengaruh dari The fed terhadap Kurs Ringgit. Pada penelitian teradahulu untuk model regresi The fed terhadap Indeks Harga Saham Gabungan Malaysia tidak ada literatur terdahulunya. Sedangkan untuk model regresi Indeks Harga Saham Malaysia terhadap Kurs Ringgit, sesuai penelitian yang dilkaukan Tsai I Chun (2012) yaitu terjadi pengaruh antara Indeks Harga Saham Malaysia terhadap Kurs Ringgit, pada periode penelitian tersebut adalah dari tahun 1992 - 2009. Dari hasil tersebut, maka dapat disimpulkan terjadi pengaruh antara The fed terhadap Kurs Ringgit hal ini dapat terlihat dari tahun 2010 - 2019 kurs ringgit juga mengalami kencederungan melemah (kenaikan) terhadap dolar amerika, dengan mediasi Indeks harga saham Malaysia sebagai mediasi perpindahan dananya. 


\section{Filipina}

\section{The fed berpengaruh terhadap Kurs Peso dengan Indeks Harga Saham Gabungan} Filipina sebagai variabel mediasinya.)

Hasil regresi yang telah dilakukan pada The fed terhadap Indeks Harga Saham Gabungan Filipina menghasilkan pengaruh positif (Probabilitas 0.0006, koefisien 3.66827), dan juga pada hasil regresi Indeks Harga Saham Gabungan Filipina terhadap Kurs Peso menghasilkan pengaruh positif (probabilitas, 0.0000, koefisien 738.0523). Hal ini dapat disimpulkan bahwa dengan menggunakan variabel mediasi Indeks Harga Saham Gabungan Filipina mengahasilkan pengaruh dari The fed terhadap Kurs Peso. Pada penelitian terdahulu untuk model regresi The fed terhadap Indeks Harga Saham Gabungan dan model regresi Indeks Harga Saham Filipina terhadap Kurs Peso tidak ada literatur terdahulunya yang penulis masukan ke dalam penulisan ini. Karena mempertimbangkan penelitian terdahulu yang harus terindeks. Dari hasil regresi, maka dapat disimpulkan terjadi pengaruh positif antara The fed terhadap Kurs Peso hal ini dapat terlihat dari tahun 2010 - 2019 Kurs peso juga mengalami kencederungan melemah (kenaikan) terhadap mata dolar amerika, dengan mediasi Indeks harga saham filipina sebagai mediasi perpindahan dana nya.

\section{Singapura}

\section{The fed terhadap Kurs dolar Singapura dengan Indeks Harga Saham Gabungan Singapura sebagai variabel mediasinya.}

Hasil regresi yang telah dilakukan pada The fed terhadap Indeks Harga Saham Gabungan Singapura menghasilkan pengaruh positif (Probabilitas 0.0007, koefisien 6.8335407), dan juga pada hasil regresi Indeks Harga Saham Gabungan Singapura terhadap kurs dolar singapura menghasilkan pengaruh negatif (probabilitas, 0.0000, koefisien -9.194035). Hal ini dapat disimpulkan bahwa dengan menggunakan variabel mediasi Indeks Harga Saham Gabungan singapura mengahasilkan pengaruh dari The fed terhadap Kurs dolar singapura. Untuk model regresi The fed terhadap Indeks Harga Saham Gabungan Singapura tidak sesuai dengan peneltiain terdahulu yang dilakukan oleh Yang Lu \& Hamori Shigeyuki (2013). Dimana The fed terhadap Indeks Harga Saham Gabungan Singapura memiliki pengaruh negatif pada tahun 1990 - 2008. Sedangkan pada model regresi penulis memiliki pengaruh positif, perbedaan ini diperkirakan karena pada periode penelitian penulis di tahun 2010 - 2019. Sehingga ada perbedaan kondisi perekonomian pada masa tersebut dengan sekarang. Kemudian pada model regresi Indeks Harga Saham Gabungan Singapura terhadap Kurs Dolar Singapura, terjadi pengaruh negatif, hal ini sesuai dengan penelitian Tsai I Chun (2012) dimana penelitian tersebut meneliti pengaruh indeks harga saham gabungan negara Singapura dengan kurs Singapura dolar pada tahun 1992 - 2009, dan akan berpengaruh negatif jika ada penurunan/ kenaikan yang cukup ekstrim. Pada penelitian penulis terjadinya pengaruh negatif, hal ini dikarenakan sejak tahun 2015 negara Singapura mengalami gejala perlambatan ekonomi hingga tahun 2019. Pengamatan penulis pada pada negara singapura karena negara tersebut memiliki ketergantungan tinggi terhadap negara Cina dalam hal ekspor sehingga ketika negara Cina melambat juga akan berdampak terhadap Singapura. Hal ini juga diperparah dengan dengan terjadinya perang dagang antara Amerika dengan Cina. Sedangkan pada kurs Singapura dolar fluktuasinya cenderung stabil.

\section{Kesimpulan}

1. Terdapat pengaruh The fed terhadap indeks harga saham pada negara-negara ASEAN-5 (Indonesia, Malaysia, Filipina, dan Singapura) kecuali pada negara Vietnam. hal ini dikarenakan hasil regresi pada negara tersebut tidak memenuhi syarat uji asumsi klasik yaitu normalitas.

2. Terdapat pengaruh indeks harga saham terhadap kurs pada negara-negara ASEAN-5 (Indonesia, Malaysia, Filipina, dan Singapura) kecuali pada negara Vietnam. hal ini dikarenakan hasil regresi pada negara tersebut tidak memenuhi syarat uji asumsi klasik yaitu normalitas. 
3. Pengaruh The fed terhadap kurs di ASEAN-5 dengan menggunakan indeks harga saham ASEAN-5 sebagai variabel mediasinya pada tahun 2010-2019. Pada negara Indonesia, Malaysia, Filipina, dan Singapura penggunakan variabel indeks harga saham gabungan dapat memediasi. Kecuali pada negara Vietnam. hal ini dikarenakan hasil regresi pada negara tersebut tidak memenuhi syarat uji asumsi klasik yaitu normalitas.

\section{DAFTAR PUSTAKA}

Aini, N. (2018, 24 Maret). Republika: Pergerakan Saham Terpengaruh Suku Bunga The $\begin{array}{llll}\text { Fed.Retrived Mei, } 2019 . & \text { From: }\end{array}$ https://www.republika.co.id/berita/ekonomi/keuangan/18/03/23/p61sb1382-pergerakansaham-terpengaruh-suku-bunga-the-fed.

Dai. (2018). Indopos: Rupiah Menguat, Perbanyak Invetasi Langsung. Retrieved Mei,2, 2019. From: https://www.indopos.co.id/read/2018/05/15/138083/rupiah-menguat-perbanyakinvestasi-langsung.

Gom, H. G. (2013). Analisis pengaruh the fed rate, indeks dow jones dan indeks nikker 225 terhadap indeks harga saham gabungan (IHSG) di Bursa Efek Indonesia (BEI) periode 2008-2013. Jurnal USU, 1(8).

Lidwina. (2019). Databoks: Indonesia Peringkat 4 Negara Tujuan Investasi Asing di Asia. $\begin{array}{llll}\text { Retrieved } 26 & \text { Desember } & 2019 . & \text { From: }\end{array}$ https://databoks.katadata.co.id/datapublish/2019/11/14/indonesia-peringkat-4-negaratujuan-investasi-asing-di-asia

Mahrofi, Z. (2018, 21 Desember). Antaranews: IHSG Melemah Karena Masih Dipengaruh Kebijakan The Fed. Retrieved Mei,2, 2019. From: https://www.antaranews.com/berita/780044/ihsg-melemah-karena-masih-dipengaruhiikebijakan-the-fed.

Mitra, R. (2017). Stock market and foreign exchange market intergration in South Africa. World Development Perspective, 6, 32 - 34.

Richard, M. (2013, 22 Maret). Bisnis: Bunga The Fed Naik, Saatnya Beli Saham! Retrieved Mei,2,2019. From: https://market.bisnis.com/read/20180322/7/752996/bunga-the-fednaik-saatnya-beli-saham.

Samsul, M. (2006). Pasar Modal dan Manajemen Portofolio. Jakarta: Erlannga.

Setiawan, H. \& Lestari, S. (2011). Perdagangan Internasional. Yogyakarta: Pustaka Nusantara.

Sukirno, S. (2011). Makro Ekonomi Teori Pengantar (Edisi Ketiga). Jakarta: Rajawali Pers.

Tang, X. \& Yao, X. (2017). Do Financial structures affect exchange rate and stock price interaction? Evidence from emerging markets. Emerging Markets Review.

Tsai, I. C. (2012). The relationship between stock price index and exchange rate in asian markets: a quantile regression approach. Journal of International Financial Markets, Institutions \& Money, 22, $609-621$.

Ugur, M. (2002). An Open Economy Macroeconomics Reader. London: The Cromwell Press, Trowbridge, Wiltshire.

Wijayaningsih, R., Rahayu, S. M., \& Saifi, M. (2016). Pengaruh bi rate, fed rate, dan kurs rupiah terhadap indeks harga saham gabungan (IHSG) (Studi pada Bursa Efek Indonesia periode 2008-2015). Jurnal Administrasi Bisnis (JAB), 33.

Winarno, W. W. (2015). Analisis Ekonometrika dan Statistika dengan EViews (Edisi 4). Yogyakarta: UPP STIM YKPN.

Yang, L. \& Hamori, S. (2013). Spillover effect os US monetary policy to ASEAN stock markets: Evidence. Pacific Basin Finance Journal.

Yanuar. (2016). Ekonomi Makro: Suatu Analisis Konteks Indonesia. https://doi.org/10.17605/OSF.IO/CTMGP 